\title{
Near Infrared Reflectance Spectroscopy: Prediksi Cepat dan Simultan Kadar Unsur Hara Makro pada Tanah Pertanian
}

\author{
Near Infrared Reflectance Spectroscopy: Fast and Simultaneous Method to Predict Soil Macro \\ Nutrients in Agricultural Soil \\ D. Devianti ${ }^{1}$, Sufardi ${ }^{2}$, Zulfahrizal ${ }^{1}$, Agus Arip Munawar ${ }^{1 *}$ \\ ${ }^{1}$ Jurusan Teknik Pertanian, Universitas Syiah Kuala, Jl. T Hasan Krueng Kalee No. 3, Kopelma Darussalam, \\ Banda Aceh 23111, Indonesia \\ 2 Jurusan Ilmu Tanah, Universitas Syiah Kuala, Jl. T Hasan Krueng Kalee No. 3, Kopelma Darussalam, \\ Banda Aceh, Indonesia \\ *Email: aamunawar@unsyiah.ac.id
}

Tanggal submisi: 6 Januari 2019; Tanggal penerimaan: 28 Februari 2019

\begin{abstract}
ABSTRAK
Tanaman dapat tumbuh ideal pada tanah dengan kadar nutrisi unsur hara yang cukup, baik hara makro maupun mikro. Jumlah atau kadar unsur hara dalam tanah dapat diketahui dengan pengujian di laboratorium yang umumnya membutuhkan waktu, melibatkan bahan kimia lain dan merusak. Sehingga diperlukan metode baru yang dapat memprediksi kadar unsur hara tanah dengan waktu yang singkat, tanpa bahan kimia, dan dapat memprediksi secara simultan. Salah satu teknologi yang dapat diterapkan untuk hal ini adalah metode near infrared reflectacne spectroscopy (NIRS). Studi ini bertujuan untuk mengkaji potensi metode NIRS sebagai metode baru yang dapat digunakan untuk prediksi kadar unsur hara makro (N, P dan K) pada tanah lahan pertanian. Spektrum inframerah untuk sampel tanah diakuisisi pada rentang panjang gelombang 1.000-2.500 nm. Spektrum tersebut kemudian dikoreksi dan diperbaiki dengan metode smoothing. Model prediksi kadar unsur hara dibangun dengan metode principal component regression (PCR) dan partial least square regression (PLSR). Akurasi hasil prediksi kemudian dibandingkan berdasarkan indikator statistik: correlation coefficient $(r)$, root mean square error (RMSEC) dan residual predictive deviation (RPD). Hasil studi menunjukkan bahwa metode NIRS mampu memprediksi kadar unsur hara makro secara cepat dan simultan dengan akurasi maksimum sebagai berikut: $r=0,97$ untuk prediksi $\mathrm{N}, \mathrm{r}=0,99$ untuk $\mathrm{P}$ dan $\mathrm{r}=0,95$ untuk prediksi $\mathrm{K}$. Dari hasil studi dapat disimpulkan bahwa metode NIRS berpotensi dan dapat diterapkan sebagai metode alternatif yang cepat dan siumltan untuk prediksi unsur hara makro pada tanah lahan pertanian.
\end{abstract}

Kata kunci: Infra-merah; unsur hara; NIRS; prediksi; tanah pertanian

\begin{abstract}
Plants need an ideal and healthy soil condition for their growth and a sufficient amount of soil macronutrients. To determine soil nutrients, several methods have been widely employed. Yet, most of them are based on solvent extraction, which is normally time-consuming, requires complicated sample preparation, and sometimes involves chemical materials. Thus, a novel, fast and simultaneous method is required as an alternative method used to predict soil macronutrients in a short period and without involving chemical materials. Near infrared spectroscopy (NIRS) can be considered for this need, since this method is fast, environmentally friendly, and non-destructive. Therefore, the main objective of this study is to apply an NIRS method to predict soil macronutrients (N, P, and K). The diffuse reflectance spectrum was acquired for soil samples in a wavelength range from 1000-2500 nm. Spectra data were corrected using a smoothing method whilst prediction models were developed using principal component regression (PCR) and partial
\end{abstract}


least square regression (PLSR). Prediction accuracy and robustness were evaluated using these following statistical indicators: correlation coefficient ( $r$ ), root mean square error (RMSEC) and residual predictive deviation (RPD). The results showed that NIRS was able to predict soil macronutrients simultaneously with a maximum correlation coefficient $r=0.97$ for $N$ prediction, $r=0.99$ for $P$ prediction, and $r=0.95$ for $K$ prediction. Thus, it may be concluded that an NIRS method is feasible to be applied as a novel, reliable and fast method to predict soil macronutrients $(\mathrm{N}, \mathrm{P}$, and $\mathrm{K})$ simultaneously.

Keywords: Infrared; macronutrients; NIRS; prediction; soil

\section{PENDAHULUAN}

Tanah merupakan media utama tempat tumbuhnya tanaman, baik itu tanaman pangan ataupun tanaman perkebunan. Secara nyata tanaman dapat tumbuh ideal pada tanah yang sehat, apabila tanah bebas dari logam berat dan subur, memiliki sifat fisik dan kimia yang sesuai dengan pertumbuhan tanaman. Kondisi tanah yang sehat secara fisik dapat terlihat secara visual seperti tekstur, struktur dan kelembaban. Sifat kimia tanah berkaitan dengan jumlah hara yang dibutuhkan oleh tanaman, dengan jumlah yang dibutuhkan akan berbeda setiap fase pertumbuhan (Wang dkk., 2018).

Kesuburan tanah sangat ditentukan oleh keberadaan unsur hara dalam tanah, baik unsur hara makro, unsur hara sekunder maupun unsur hara mikro. Unsur hara makro meliputi nitrogen $(\mathrm{N})$, pospor $(\mathrm{P})$, dan kalium (K). Sedangkan unsur hara sekunder meliputi calcium (Ca), magnesium (Mg), dan sulfur (S). Setiap tanaman membutuhkan hara makro dalam jumlah yang besar seperti nitrogen $(\mathrm{N})$, potasium $(\mathrm{P})$, dan kalium (K). Unsur hara makro dibutuhkan oleh semua tanaman terutama pada fase pertumbuhan. Sedangkan unsur hara mikro diperlukan dalam jumlah sedikit namun sifatnya sangat esensial (Xing dkk., 2019; Zhao dkk., 2017).

Unsur hara dalam tanah sulit diprediksi diperlukan pengujian secara laboratorium dan membutuhkan waktu, sedangkan kebutuhan hara harus segera diketahui agar tanaman dapat tumbuh secara ideal. Unsur hara di dalam tanah harus dalam jumlah cukup dan komposisi seimbang. Sebab bila salah satu unsur berkurang maka dapat mengakibatkan pertumbuhan tanaman menjadi tidak wajar. Tiap unsur hara mempunyai tugas tertentu dan tidak satu unsur harapun yang dapat menggantikannya secara sempurna (Christy, 2008).

Penambahan unsur hara oleh petani biasanya disesuaikan dengan dosis takaran per fase tanaman, hal ini mengakibatkan jumlah hara yang dibutuhkan menjadi tidak seimbang, atau pada fase tertentu tanaman kekurangan unsur hara dan pada fase lainnya tanaman kelebihan unsur hara. Implikasi hal ini mengakibatkat upaya pemupukan tidak efisien dari segi ekonomi dan tidak ramah lingkungan. Kelebihan hara dapat mengakbatkan pencemaran tanah yang mengakibatkan unsur hara tersebut menjadi toksid terhadap tanaman. Dampak hal ini terjadinya kerusakan jaringan tanaman sehingga tanaman tidak mampu berproduksi secara ideal (Shen dkk, 2013).

Oleh sebab itu, deteksi atau pendugaan kadar unsur hara pada tanah harus dilakukan guna memonitor kondisi kesehatan dan kesuburan tanah, terutama tanah yang digunakan untuk aktivitas pertanian dan peternakan. Tindakan monitoring ini dilakukan agar kita dapat menentukan tindakan pencegahan ataupun tindakan lanjutan yang harus dilakukan guna menjaga kondisi kesehatand dan kesuburan tanah (Corradini dkk., 2019).

Secara konvensional, kandungan unsur hara pada tanah dapat dilakukan dengan melakukan uji laboratorium pada sampel tanah. Hal ini terkadang memerlukan waktu yang cukup lama dan tentu saja melibatkan beberapa bahan kimia yang sudah tentu tidak efektif dan dapat mengakibatkan tambahan pencemaran lingkungan (Chatterjee dkk., 2018; Jarmer dkk., 2008).

Pada saat ini, perhatian dan usaha yang besar terus dikembangkan oleh para peneliti untuk mencari metode alternatif yang cepat, efektif, ramah lingkungan dan bersifat tidak merusak (non-destructive) untuk memprediksi kadar unsur hara di tanah. Salah satu teknologi saat ini yang sedang berkembang dan dapat digunakan untuk mendeteksi/memprediksi kandungan unsur hara adalah teknologi pantulan infra merah dekat atau near infrared reflectance spectroscopy (NIRS). Keunggulan metode ini antara lain: tidak merusak bahan, persiapan sampel yang relatif mudah, tidak memerlukan bahan kimia serta dapat menduga kandungan beberapa logam berat secara simultan (Munawar dkk., 2013; Ludwig dkk., 2006; Wang dkk., 2019).

Teknologi NIRS bekerja berdasarkan prinsip bahwa setiap bahan biologik, termasuk tanah memiliki karakteristik elektromagnetik tertentu dimana spektrum yang dihasilkan dapat dianalisa guna mendapatkan informasi mengenai kandungan organik tanah termasuk untuk memprediksi kandungan unsur hara sebagai 
indikator tingkat kesuburan dan kesehatan kondisi tanah. Infrared spectroscopy merupakan teknik atau metode yang menggunakan radiasi sinar inramerah dekat atau near infrared (NIR) untuk menganalisa komposisi kimia dari bahan organik. Informasi kandungan kimia ini didapatkan berdasarkan reaksi dari bahan biologik setelah diberi radiasi sinar NIR.

Sinar inframerah dekat berada pada kisaran panjang gelombang $780 \mathrm{~nm}$ sampai $2500 \mathrm{~nm}$ atau berada di atas sinar tampak/visible (Nicolaï dkk., 2007). Ketika sebuah sinar yang berasal dari sumber cahaya jatuh mengenai obyek biologik, maka akan terjadi interaksi antara obyek dan sinar tersebut dimana obyek tersebut akan memberi respon berupa pantulan (reflectance), serapan (absorbance) dan terusan (transmittance) (Munawar dkk, 2016).

Studi awal yang dilakukan beberapa peneliti menyimpulkan bahwa teknologi NIR mampu dijadikan sebagai tools untuk menduga kualitas kondisi tanah seperti prediki kelembaban tanah (Vaknin dkk., 2011), kadar bahan organik pada tanah (Kooistra dkk., 2001), Kandungan tanah lempung (Martínez-España dkk, 2018), kandungan Fe pada tanah (Waruru dkk., 2016), Karakteristik tanah (Guo dkk., 2017; Peltre dkk., 2011). serta kontaminasi tanah (Guo dkk., 2017; Mohamed dkk, 2018; Moros dkk, 2009; Peltre dkk., 2011; SorianoDisla dkk., 2019). Namun begitu, studi dan penelitian lebih lanjut masih perlu dilakukan guna memperbaiki spektrum pantulan yang dihasilkan agar hasil prediksi lebih akurat. Selain itu, metode regresi model juga perlu penelitian lebih lanjut terutama penggunaan metode regresi non-linier untuk membangun model prediksi kandungan logam berat pada tanah di lahan pertanian (Xu dkk, 2018). Tujuan dari studi ini adalah untuk mengkaji secara detail karakteristik teknologi near infrared spectroscopy sebagai metode baru yang cepat (rapid) dan efektif untuk memprediksi kandungan konsentrasi unsur hara (unsur N, P, K) secara simultan pada tanah di lahan pertanian.

\section{METODE PENELITIAN}

\section{Sampel Tanah}

Sampel tanah yang digunakan dalam studi ini adalah sampel tanah yang diambil pada kedalaman $20 \mathrm{~cm}$ atau dalam kategor top soil. Tanah diambil dari land use sawah dan ladang di wilayah Blang Bintang dan sekitarnya, Kabupaten Aceh Besar, Provinsi Aceh. Sampel tanah kemudian dibawa ke laboratorium untuk dibersihkan dari kerikil dan sisa tanaman yang ada, kemudian disimpan selama 2 hari pada suhu $27^{\circ} \mathrm{C}$ untuk penyeragaman suhu dan kelembaban.

\section{Akuisisi Spektrum Infrared untuk Sampel Tanah}

Spektrum inframerah dekat (near infrared) untuk sampel tanah diakuisi dengan menggunakan instrumen infrared spectroscopy (FT-NIR Thermo Nicolet Antaris TM II, dengan konfigurasi alur kerja alat (workflow) dibangun dengan menggunakan perangkat lunak terintegrasi Thermo Integration $\AA$. Workflow dibuat untuk mengatur alat agar bekerja untuk mengakuisisi spektrum diffuse reflectance, memindai sampel sebanyak 64 kali lalu merata-ratakan hasilnya, menyimpan hasil pemindaian dalam 2 format file yakni *.SPA dan *.CSV.

Method development sampling (MDS) dipilih sebagai metode akuisisi spektrum dimana kalibrasi background dilakukan tiap jam. Rentang panjang gelombang yang dipakai adalah $1000-2500 \mathrm{~nm}$ dengan interval sekitar $2 \mathrm{~nm}$. Pengambilan spektrum sampel tanah dilakukan dengan menempatkan sampel tanah ( $\pm 80 \mathrm{~g}$ ) pada mangkuk sampel (sample cup holder) dan diatur agar mangkuk sampel tersebut berputar 360 derajat selama proses pemindaian.

\section{Pengukuran Kadar Unsur Hara Aktual}

Sampel tanah yang telah diakusi spektrumnya, kemudian segera dibawa ke laboratorium untuk dilakukan pengukuran dan analisa kandungan unsur hara. Sebelum analisa ini, sampel tanah dipre-proses pada alat electric heating board. Kadar N, P, dan K aktual pada sampel tanah dikur dengan menggunakan metode standard laboratorium. Metode atomic absorption flame spectrometry digunakan untuk pengukuran akdar unsur hara aktual pada tanah.

\section{Koreksi Spektrum Infrared}

Sebelum digunakan untuk analisa data (membangun model prediksi), spektrum NIR untuk semua sampel tanah terlebih dahulu dilakukan koreksi spektrum. Hal ini bertujuan untuk menghilangkan berbagai macam "noises" pada spektrum sampel tanah agar hasil prediksi logam berat lebih akurat (Mouazen dkk., 2010). Metode yang digunakan dalam koreksi spektrum ini adalah metode smoothing dimana data spektrum akan diperbaiki terutama pada bagian yang banyak mengandung noise atau gangguan akibat pembauran cahaya (Munawar dkk., 2016).

\section{Model Prediksi Kadar Unsur Hara N, P, dan K}

Kandungan unsur hara pada sampel tanah diprediksi berdasarkan spektrum NIR yang dihasilkan melalui proses kalibrasi model (pembangunan model). Model prediksi dibangun dengan meregresikan antara spektrum NIR (variable $\mathrm{X}$ ) dengan kadar $\mathrm{N}, \mathrm{P}$, dan $\mathrm{K}$ (variabel $\mathrm{Y}$ ) dari hasil pengukuran di laboratorium. 
Metode regresi yang digunakan adalah metode principal component regression (PCR) dan partial least square regression (PLSR). Hasil prediksi dari kedua metode regresi ini kemudian dibandingkan dan dipilih metode regresi terbaik berdasarkan akurasi dan kehandalan model dalam memprediksi kadar unsur hara pada tanah pertanian.

\section{HASIL DAN PEMBAHASAN}

\section{Fitur Spektrum Tanah}

Secara umum, tipikal spektrum diffuse reflectance pada rentang spektrum infrared dengan panjang gelombang 1.000-2.500 nm untuk sampel tanah dalam studi ini terlihat seperti pada Gambar 1. Dari spektrum ini terlihat bahwa fitur spectrum mengindikasikan keberadaan bahan organik dan kandungan nutrisi dan properties kimia dari tanah akibat interaksi ikatan molekul O-H, C-H, C-O, dan $\mathrm{N}-\mathrm{H}$.

Bentuk spektrum diffuse reflectance untuk sampel tanah ini terjadi akibat adanya perubahan vibrasi energi dalam bentuk overtone, bending dan stretching (Nicolaï dkk., 2007). Unsur karbonat mendominasi properties kimia pada sampel tanah. Dari gambar 5 diatas, dapat dilihat bahwa terdapat panjang gelombang relevan atau band assignment untuk ikatan kimia yang mencerminkan properties dan nutrisi tanah seperti ikatan $\mathrm{C}-\mathrm{H}$ pada bands $1.0701 .090 \mathrm{~nm}, 1.1051 .210 \mathrm{~nm}, 2.3252 .380$ nm, O-H pada bands 1.430 dan $1.910 \mathrm{~nm}, \mathrm{C}-\mathrm{H}-\mathrm{O}$ pada bands $1.6801 .720 \mathrm{~nm}, 2.300-2.490 \mathrm{~nm}$.

\section{Prediksi Kadar Nitrogen, Posfor, dan Kalium (NPK) Tanah}

Lokasi lahan pertanian pada penelitian ini meliputi wilayah Aceh Besar dan Banda Aceh dengan land-use utama nya adalah tanah sawah dan ladang. Sampel tanah diambil pada lokasi tersebut dengan jumlah titik pengkuran adalah 18 titik lokasi dengan asumsi adanya perbedaan kadar unsur hara tanah yang terdistribusi, sehingga didapatkan rentang data yang cukup. Adapun deskripsi statistik data kadar unsur hara NPK pada tanah di lokasi penelitian tertera pada Tabel 1.

Tabel 1. Deskripsi statistik kadar NPK pada 18 titik pengukuran hasil pengujian laboratorium

\begin{tabular}{lllll}
\hline Unsur hara & Mean & Min & Max & Std.deviasi \\
\hline $\mathrm{N}$ & 0,10 & 0,019 & 0,48 & 0,11 \\
$\mathrm{P}$ & 12,50 & 0,12 & 40,92 & 13,36 \\
$\mathrm{~K}$ & 0,55 & 0,26 & 1,13 & 0,19 \\
\hline
\end{tabular}

Kadar unsur hara NPK pada sampel tanah diprediksi dengan menggunakan data spektrum infrared yang telah didapatkan. Pada tahap awal, model prediksi dibangun dengan meregresikan data spektrum Raw (tanpa perbaikan spektrum) dengan data kadar NPK aktual hasil pengukuran di laboratorium. Metode regresi yang digunakan adalah principal component regression (PCR) dan partial least square regression (PLSR). Secara umum, kadar NPK tanah dapat diprediksi dengan baik menggunakan data spektrum transmisi

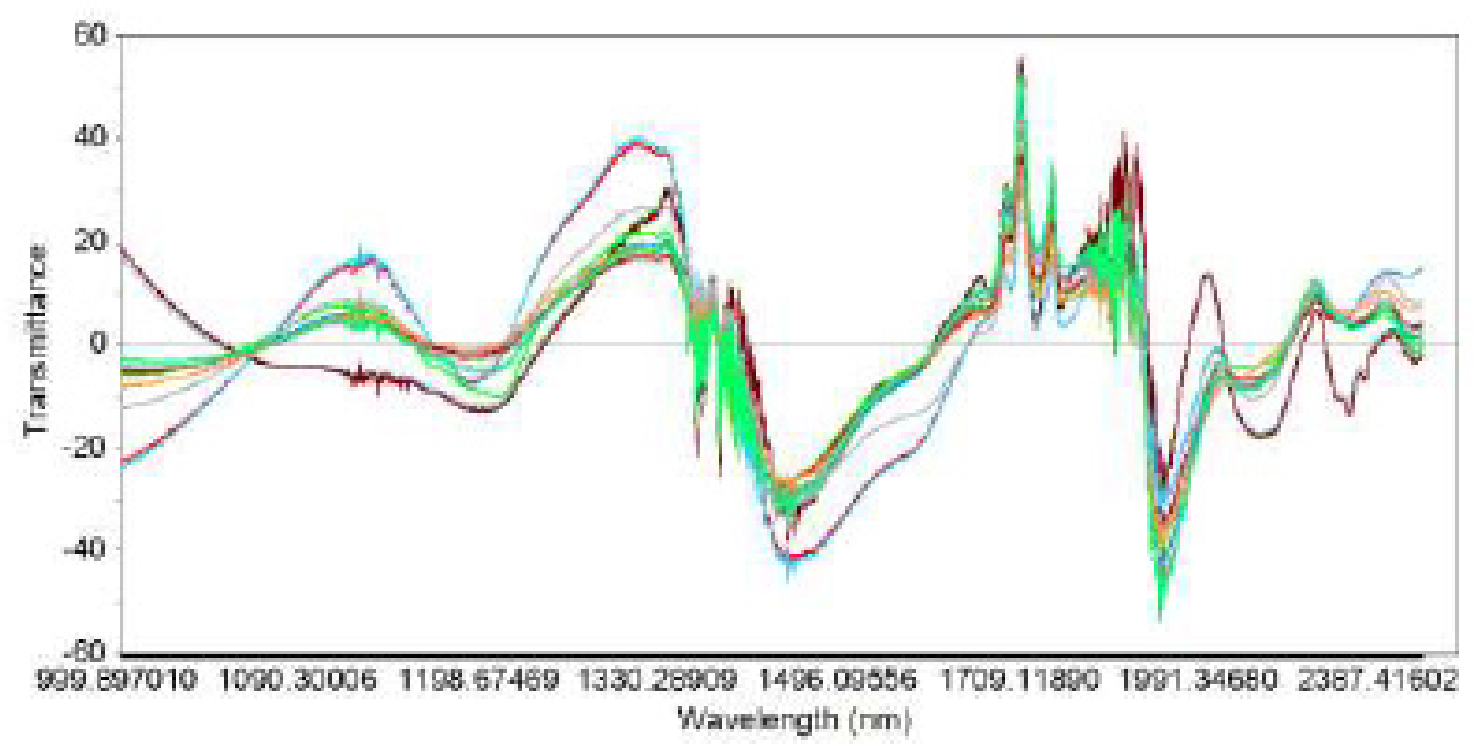

Gambar 1. Fitur spektrum diffuse reflectance sampel tanah pada rentang panjang gelombang infrared. 


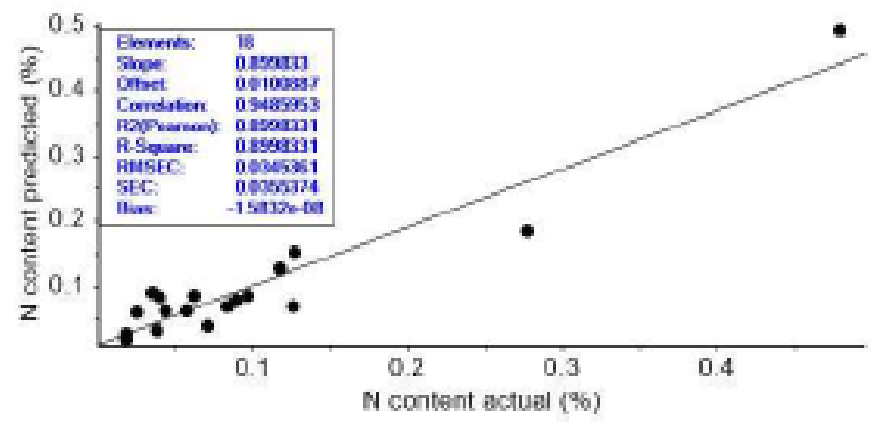

Gambar 2. Scatter plot prediksi kadar Nitrogen (N) dengan metode principal component regression (PCR) menggunakan data spektrum NIR

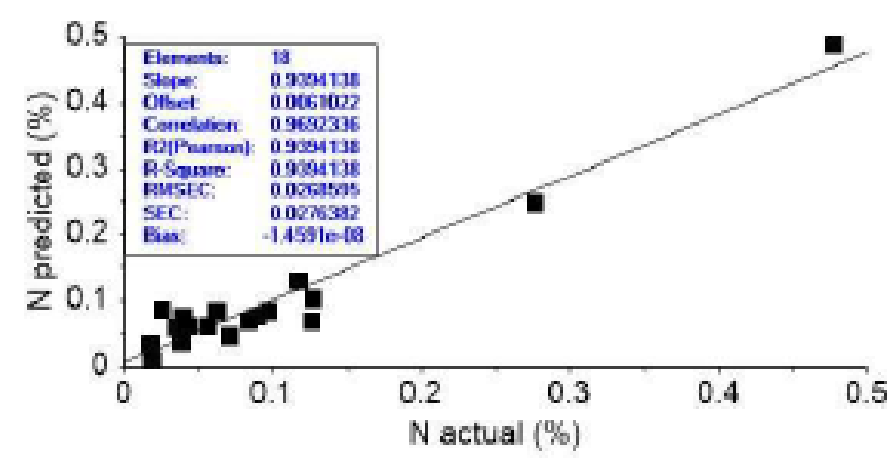

Gambar 3. Scatter plot prediksi kadar Nitrogen (N) dengan metode partial least square regression (PLSR) menggunakan data spektrum NIR

Raw (tanpa perbaikan) dengan koefisien korelasi $r=$ 0,95 , serta residual predictive deviation (RPD) index, $\mathrm{RPD}=3,25$ yang mana berdasarkan literatur, tergolong pada excellent model performance. Scatter plot antara $\mathrm{N}$ aktual dengan $\mathrm{N}$ prediksi infrared dengan metode $\mathrm{PCR}$ terlihat pada Gambar 2. Selain itu, prediksi kadar N pada sampel tanah juga dibangun dengan menggunakan metode partial least square regression (PLSR) dan menghasilkan hasil prediksi yang lebih baik dari metode PCR. Koefisien korelasi yang dihasilkan meningkat menjadi 0,97. Scatter plot hasil prediksi kadar nitrogen pada sampel tanah terlihat pada Gambar 3.

Model prediksi unsur hara yang didapatkan dalam studi ini adalah model kalibrasi spektrum inframerah pada rentang panjang gelombangf $1.000-2.500 \mathrm{~nm}$. Model prediksi ini dapat juga digunakan untuk memprediksi hara pada tanah dengan land use lain selain sawah dan ladang, dengan catatan bahwa spektrum sampel tanah yang diambil adalah pada rentang panjang gelombang tersebut.

Unsur hara penting lainnya dalam tanah selain $\mathrm{N}$, adalah kadar P dan K. Kalibrasi model, digunakan untuk prediksi kadar $\mathrm{P}$ dan $\mathrm{K}$ pada tanah, dibangun dengan metode principal component regression (PCR) dan partial least square regression (PLSR). Hasil prediksi unsur hara $P$ dengan metode regresi PCR dan PLSR terlihat pada pada Gambar 4 dan 5. Berdasarkan hasil prediksi, didapat bahwa prediksi kadar $\mathrm{P}$ pada sampel tanah juga dapat diprediksi dengan baik oleh kedua pendekatan regresi tersebut dengan koefisien korelasi yang dihasilkan untuk prediksi unsur makro $\mathrm{P}$ metode regresi PCR adalah sebesar 0,95, sedangkan dengan metode regresi PLSR adalah 0,99.

Berdasarkan hasil tersebut, dapar terlihat bahwa metode regresi PLSR memberikan hasil prediksi yang lebih akurat dibandingkan metode regresi PCR. Hal ini disebabkan pada metode metode PLSR, variabel unsur hara, yang merupakan variabel terikat $(\mathrm{Y})$, diikutsertakan dalam proses transformasi dan projeksi variabel bebas (X) yang merupakan data sepktrum NIR. Kovariate dari kedua variabel tersebut akan diwakili menjadi varibel baru yang biasanya disebut dengan variabel laten (LV). Koefisien error prediksi yang dihasilkan untuk prediksi $P$ dengan metode PLSR juga lebih rendah dibandingkan dengan metode PCR.

Selanjutnya, parameter unsur hara Kalium (K) juga diprediksi dengan membangun model prediksi berbasis data spektrum NIR. Metode regresi PCR dan PLSR

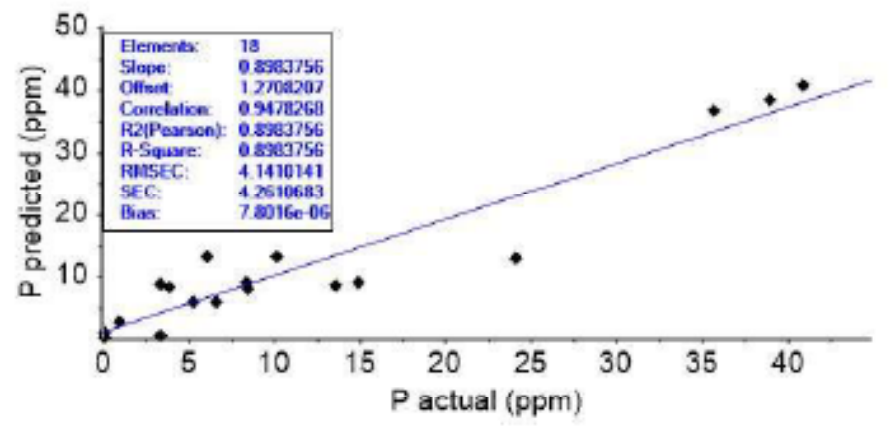

Gambar 4. Scatter plot prediksi kadar Posfor $(P)$ dengan metode principal component regression (PCR) menggunakan data spektrum NIR

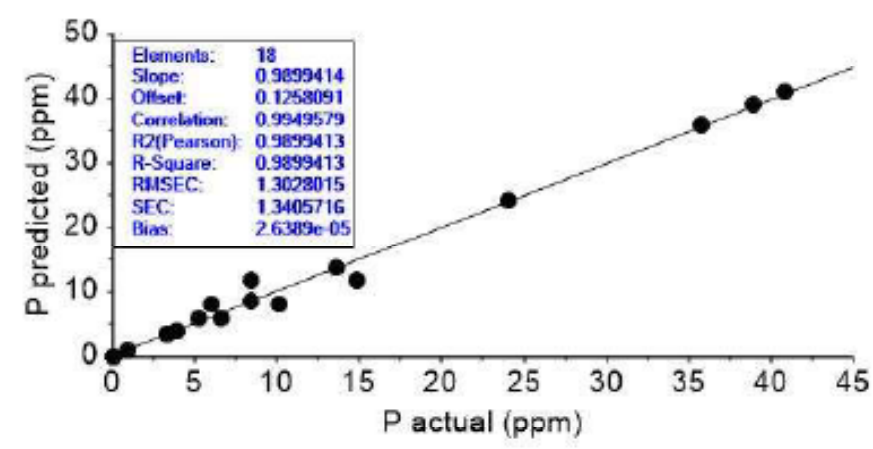

Gambar 5. Scatter plot prediksi kadar Posfor (P) dengan metode partial least square regression (PLSR) menggunakan data spektrum NIR 


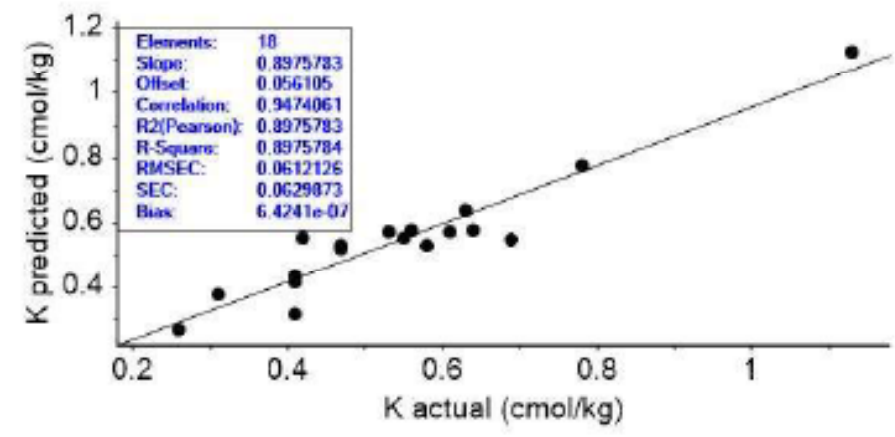

Gambar 6. Scatter plot prediksi kadar Kalium (K) dengan metode principal component regression (PCR) menggunakan data spektrum NIR

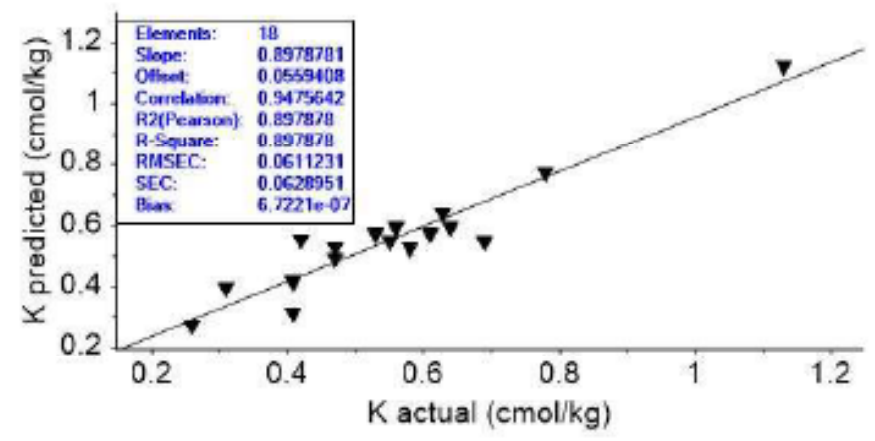

Gambar 7. Scatter plot prediksi kadar Kalium (K) dengan metode partial least square regression (PLSR) menggunakan data spektrum NIR

kembali digunakan untuk membangun model tersebut. Hasil prediksi $\mathrm{K}$ dengan metode PCR menghasilkan koefisien korelasi sebesar 0,95 dan galat (error) prediksi (RMSEC) sebesar 0,06. Hasil prediksi yang relatif sama didapatkan ketika model prediksi $\mathrm{K}$ dibangun dengan metode regresi PLSR, dimana koefisien korelasi ( $r$ ) yang dihasilkan adalah 0,95 dan galat prediksi RMSEC sebesar 0,06. Namun demikian, PLSR tetap lebih baik karena hanya melibatkan 5 laten variabel (LV) dibandingkan PCR yang memerlukan 7 variabel laten (PC) untuk menghasilkan hasil prediksi tersebut. Berdasarkan beberapa literatur (Cozzolino dkk., 2011, Mouazen dkk., 2010, Workman, 2004) menyatakan bahwa model prediksi dengan jumlah variabel laten paling sedikit adalah lebih baik dan efisien dibandingkan model prediksi dengan jumlah LV atau PC yang lebih banyak. Scatter plot hasil prediksi $\mathrm{K}$ dengan metode regresi PCR dan PLSR dapat terlihat pada Gambar 6 dan 7.

Dari hasil prediksi tersebut di atas, terlihat bahwa prediksi kadar unsur hara $\mathrm{N}, \mathrm{P}$ dan $\mathrm{K}$ secara umum dapat diprediksi dengan baik oleh teknologi NIR dengan bantuan metode PCR dan PLSR. Dari hasil akurasi dan kehandalan, terlihat bahwa metode PLSR memberikan hasil prediksi lebih baik daripada metode PCR. Hal ini disebabkan karena pada prosesnya, metode PLSR melibatkan variavle $\mathrm{Y}$ yakni kadar $\mathrm{N}, \mathrm{P}$ dan $\mathrm{K}$ dalam proses kalibrasi model. Berbeda dengan PCR yang hanya melibatkan variable $X$ (data spektrum IR) pada saat ekstraksi data menjadi variabel laten.

\section{KESIMPULAN}

Spektrum inframerah (infrared) untuk sampel tanah secara umum mencirikan informasi parameter kimia dari tanah termasuk kadar nutrisi hara makro pada tanah. Parameter kimia ini didapatkan dengan membangun model prediksi dengan pendekatan metode multivariate yang sesuai. Dalam studi ini, didapatkan bahwa metode regresi partial least square regression (PLSR) memberikan hasil prediksi lebih akurat dan lebih baik debandingkan metode regresi principal component regression (PCR) dengan koefisien korelasi maksimum sebesar 0,99. indeks kehandalan model prediksi RPD = 3,51. Dari hasi studi dapat disimpulkan bahwa teknologi NIR mampu dijadikan sebagai metode alternatif yang cepat, efisien dan ramah lingkungan dalam memprediksi kadar N, P, dan K pada tanah di lahan pertanian.

\section{UCAPAN TERIMA KASIH}

Ucapan terima kasih dan penghargaan kami sampaikan kepada DRPM KemristekDikti atas bantuan dana melalui program penelirian dasar unggulan perguruan tinggi (PDUPT) tahun anggaran 2017-2018.

\section{KONFLIK KEPENTINGAN}

Penulis menyatakan bahwa dalam karya ilmiah ini tidak ada conflict of interest antara penulis dan juga pihak lainnya.

\section{DAFTAR PUSTAKA}

Chatterjee, S., Dey, N., \& Sen, S. (2018). Soil moisture quantity prediction using optimized neural supported model for sustainable agricultural applications. Sustainable Computing: Informatics and Systems. https://doi. org/10.1016/j.suscom.2018.09.002.

Christy, C. D. (2008). Real-time measurement of soil attributes using on-the-go near infrared reflectance spectroscopy. Computers and Electronics in Agriculture, 61(1), 10-19. https://doi.org/10.1016/j.compag.2007.02.010.

Corradini, F., Bartholomeus, H., Huerta Lwanga, E., Gertsen, H., \& Geissen, V. (2019). Predicting soil microplastic 
concentration using vis-NIR spectroscopy. Science of the Total Environment, 650, 922-932. https://doi. org/10.1016/j.scitotenv.2018.09.101.

Guo, L., Zhao, C., Zhang, H., Chen, Y., Linderman, M., Zhang, Q., \& Liu, Y. (2017). Comparisons of spatial and nonspatial models for predicting soil carbon content based on visible and near-infrared spectral technology. Geoderma, 285, 280-292. https://doi.org/10.1016/j. geoderma.2016.10.010.

Jarmer, T., Vohland, M., Lilienthal, H., \& Schnug, E. (2008). Estimation of Some Chemical Properties of an Agricultural Soil by Spectroradiometric Measurements. Pedosphere, 18(2), 163-170. https://doi.org/10.1016/ s1002-0160(08)60004-1.

Kooistra, L., Wehrens, R., Buydens, L. M. C., Leuven, R. S. E. W., \& Nienhuis, P. H. (2001). Possibilities of soil spectroscopy for the classification of contaminated areas in river floodplains. ITC Journal, 3(4), 337-344. https:// doi.org/10.1016/S0303-2434(01)85041-8.

Ludwig, B., Schmilewski, G., \& Terhoeven-Urselmans, T. (2006). Use of near infrared spectroscopy to predict chemical parameters and phytotoxicity of peats and growing media. Scientia Horticulturae, 109(1), 86-91. https://doi.org/10.1016/j.scienta.2006.02.020.

Martínez-España, R., Bueno-Crespo, A., Soto, J., Janik, L. J., \& Soriano-Disla, J. M. (2018). Developing an intelligent system for the prediction of soil properties with a portable mid-infrared instrument. Biosystems Engineering, 7. https://doi.org/10.1016/j.biosystemseng.2018.09.013.

Mohamed, E. S., Saleh, A. M., Belal, A. B., \& Gad, A. A. (2018). Application of near-infrared reflectance for quantitative assessment of soil properties. Egyptian Journal of Remote Sensing and Space Science, 21(1), 1-14. https://doi.org/10.1016/j.ejrs.2017.02.001.

Moros, J., Martínez-Sánchez, M. J., Pérez-Sirvent, C., Garrigues, S., \& de la Guardia, M. (2009). Testing of the Region of Murcia soils by near infrared diffuse reflectance spectroscopy and chemometrics. Talanta, 78(2), 388398. https://doi.org/10.1016/j.talanta.2008.11.041.

Mouazen, A. M., Kuang, B., De Baerdemaeker, J., \& Ramon, H. (2010). Comparison among principal component, partial least squares and back propagation neural network analyses for accuracy of measurement of selected soil properties with visible and near infrared spectroscopy. Geoderma, 158(1-2), 23-31. https://doi.org/10.1016/j. geoderma.2010.03.001.

Munawar, A. A., Hörsten, D. V., Mörlein, D., Pawelzik, E., \& Wegener, J. K. (2013). Rapid and non-destructive prediction of mango sweetness and acidity using near infrared spectroscopy. In Lecture Notes in Informatics (LNI), Proceedings - Series of the Gesellschaft fur Informatik (GI) (Vol. P-211).
Munawar, A. A., von Hörsten, D., Wegener, J. K., Pawelzik, E., \& Mörlein, D. (2016). Rapid and non-destructive prediction of mango quality attributes using Fourier transform near infrared spectroscopy and chemometrics. Engineering in Agriculture, Environment and Food, 9(3). https://doi. org/10.1016/j.eaef.2015.12.004.

Nicolaï, B. M., Beullens, K., Bobelyn, E., Peirs, A., Saeys, W., Theron, K. I., \& Lammertyn, J. (2007). Nondestructive measurement of fruit and vegetable quality by means of NIR spectroscopy: A review. Postharvest Biology and Technology, 46(2), 99-118. https://doi.org/10.1016/j. postharvbio.2007.06.024

Peltre, C., Thuriès, L., Barthès, B., Brunet, D., Morvan, T., Nicolardot, B., ... Houot, S. (2011). Near infrared reflectance spectroscopy: A tool to characterize the composition of different types of exogenous organic matter and their behaviour in soil. Soil Biology and Biochemistry, 43(1), 197-205. https://doi.org/10.1016/j. soilbio.2010.09.036.

Shen, Z. Q., Shan, Y. J., Peng, L., \& Jiang, Y. G. (2013). Mapping of total carbon and clay contents in glacial till soil using On-the-Go Near-Infrared reflectance spectroscopy and partial least squares regression. Pedosphere, 23(3), 305311. https://doi.org/10.1016/S1002-0160(13)60020-X.

Soriano-Disla, J. M., Janik, L. J., Forrester, S. T., Grocke, S. F., Fitzpatrick, R. W., \& McLaughlin, M. J. (2019). The use of mid-infrared diffuse reflectance spectroscopy for acid sulfate soil analysis. Science of the Total Environment, 646, 1489-1502. https://doi.org/10.1016/j. scitotenv.2018.07.383.

Vaknin, Y., Ghanim, M., Samra, S., Dvash, L., Hendelsman, E., Eisikowitch, D., \& Samocha, Y. (2011). Predicting Jatropha curcas seed-oil content, oil composition and protein content using near-infrared spectroscopy-A quick and non-destructive method. Industrial Crops and Products, 34(1), 1029-1034. https://doi.org/10.1016/j. indcrop.2011.03.011

Wang, K., Zhao, Y., Yang, Z., Lin, Z., Tan, Z., Du, L., \& Liu, C. (2018). Concentration and characterization of groundwater colloids from the northwest edge of Sichuan basin, China. Colloids and Surfaces A: Physicochemical and Engineering Aspects, 537(September 2017), 85-91. https://doi.org/10.1016/j.colsurfa.2017.08.032.

Wang, L., Cheng, Y., Lamb, D., Dharmarajan, R., Chadalavada, S., \& Naidu, R. (2019). Application of infrared spectrum for rapid classification of dominant petroleum hydrocarbon fractions for contaminated site assessment. Spectrochimica Acta - Part A: Molecular and Biomolecular Spectroscopy, 207, 183-188. https://doi.org/10.1016/j. saa.2018.09.024.

Waruru, B. K., Shepherd, K. D., Ndegwa, G. M., \& Sila, A. M. (2016). Estimation of wet aggregation indices using soil properties and diffuse reflectance near infrared spectroscopy: An application of 
classification and regression tree analysis. Biosystems Engineering, 152, 148-164. https://doi.org/10.1016/j. biosystemseng.2016.08.003.

Xing, Z., Tian, K., Du, C., Li, C., Zhou, J., \& Chen, Z. (2019). Agricultural soil characterization by FTIR spectroscopy at micrometer scales: Depth profiling by photoacoustic spectroscopy. Geoderma, 335(August 2018), 94-103. https://doi.org/10.1016/j.geoderma.2018.08.003.

Xu, S., Zhao, Y., Wang, M., \& Shi, X. (2018). Comparison of multivariate methods for estimating selected soil properties from intact soil cores of paddy fields by Vis-NIR spectroscopy. Geoderma, 310(September 2017), 29-43. https://doi.org/10.1016/j.geoderma.2017.09.013.

Zhao, L., Hong, H., Liu, J., Fang, Q., Yao, Y., Tan, W., ... Algeo, T. J. (2017). Assessing the utility of visibleto-shortwave infrared reflectance spectroscopy for analysis of soil weathering intensity and paleoclimate reconstruction. Palaeogeography, Palaeoclimatology, Palaeoecology, 512, 80-94. https://doi.org/10.1016/j. palaeo.2017.07.007. 